\title{
Statistical analysis of the structure and dynamics of material and human resources in public education over the past two academic years in Bacau
}

\author{
Eugenia Harja, „Vasile Alecsandri” University of Bacau, Romania
}

\begin{abstract}
The public university education in Bacau, represented by "Vasile Alecsandri" University from Bacau has developed over the past two years not only in terms of student numbers, but as human and material resources available to them. After the number of students per teacher, public higher education from Bacau is situated on the second place after Iasi, the number of teachers representing $1 \%$ of the country. The structure by scientific degrees of teachers has improved in the last year, reaching over 36\% professors and lecturers and 144 PhDs. Over 55\% of the teachers are younger than 40 years.

The material basis has improved both quantitatively and qualitatively by putting into use a new building, bringing an additional 27 classrooms and 11 seminar rooms and providing the conditions of modern higher education.
\end{abstract}

\section{Keywords}

Teaching staff, PhDs, students, lecture rooms

JEL Codes: I21, C10

Developing a quality high education implies adequate resources, both human and material. Of 304 existing teachers in higher education from Bacau at the beginning of $2008 / 2009$ academic year, $86.2 \%$ belonged to public education. If at that moment the average of the country that was for the number of students per teacher was 28 in total, and in the Northeast region of 20 students, Bacau county had an average of 25 students / teacher. Bacau public education has an average of 20 students / teacher; compared to 19, the average of the region and to 18 , the average of the country, and also compared to 55, as the private schools from Bacau had.

From this point of view, Bacau County ranks second in the region, after Iasi, in public education.

The number of teachers in the public higher education from Bacau represents $1.0 \%$ of the total country for this form of property, being ranked 15 in the ranking counties. Human resources of the university were in a total of 404 persons at the beginning of the academic year 2009/2010, decreasing by 3.6\% (-15 persons) prior to beginning. Staff reduction occurred in all categories except the auxiliary teaching staff, where it has remained constant at 20 employees. Thus, maintenance and operational personnel at the beginning of the academic year was $7.3 \%$ lower (-6 persons) and the administrative staff with $-4.3 \%(-2$ employees). 
$\underline{\text { Studies and Scientific Researches - Economic Edition, no. 15, } 2010}$

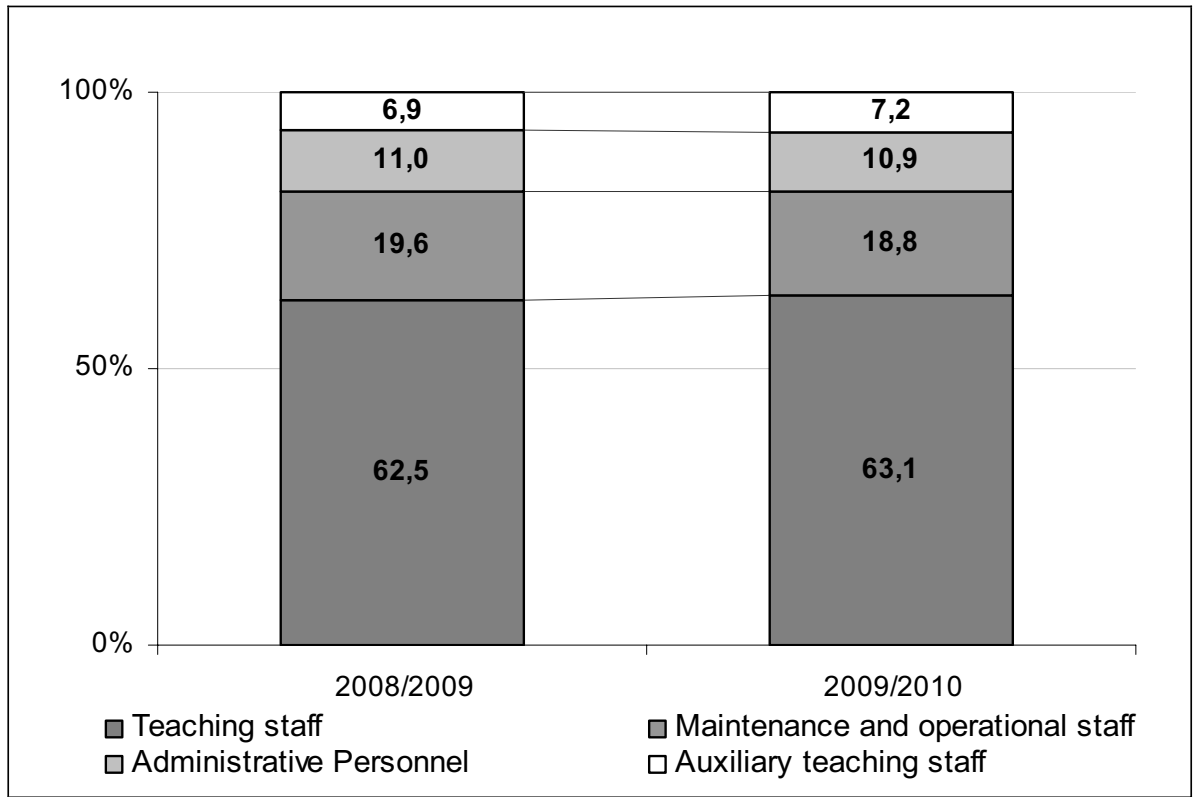

Figure 1. Structure of the personell at the beginning of the university year (\%) Source: D.J.S. Bacău

The number of holder university teachers was at the beginning of this academic year of 255 people, with $-2.7 \%$ ( -7 person) prior to the previous beginning university year. It grew its share in total from $62.5 \%$ in $2008 / 2009$ to $63.1 \%$ in $2009 / 2010$, due to the decrease in a higher extend in the administrative and maintenance staff.

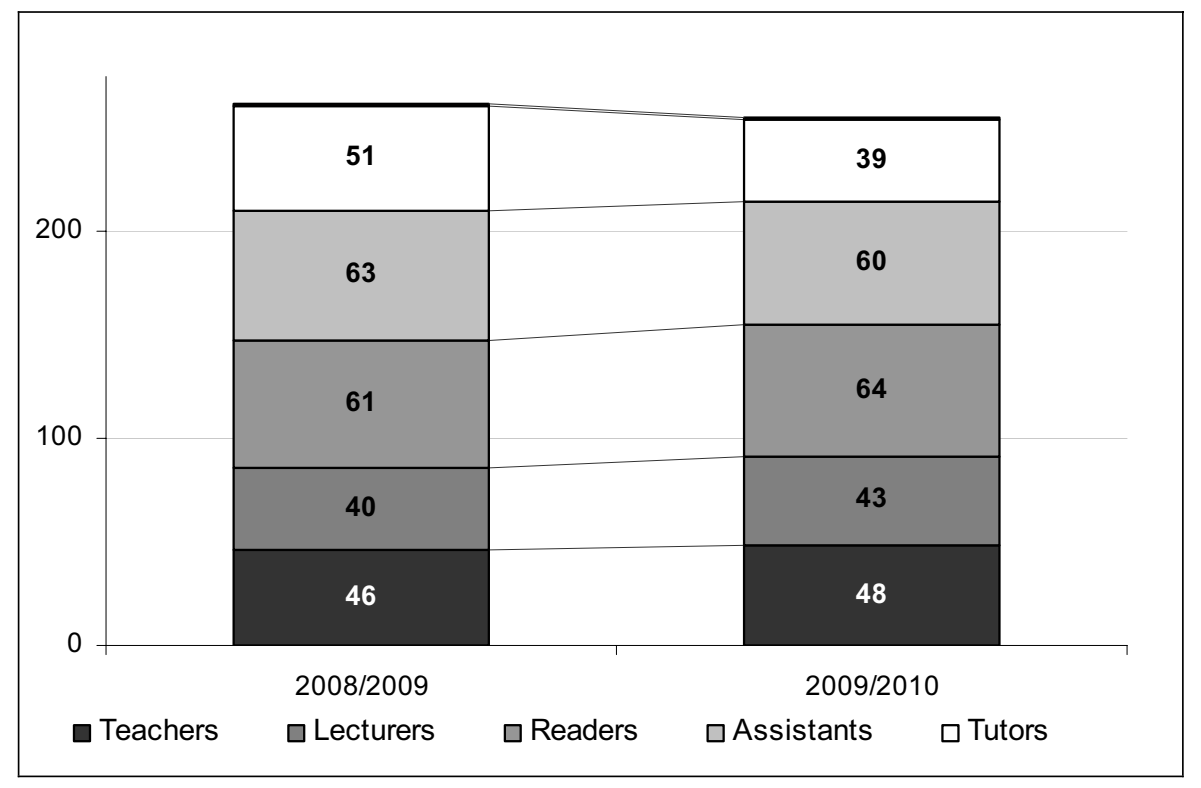

Figure 2. Teaching staff at the beginning of the university year Source: D.J.S. Bacău 
It has increased the proportion of teachers in higher degrees (lecturers and professors) in total, from $33.3 \%$ to $36.1 \%$.

It is maintained a good proportion of age groups, the teachers share until 40 years being of $55.7 \%$ in total, this year.

By age and grade comparative education distribution in the past two years is apparent in the following histograms.

University year 2008-2009
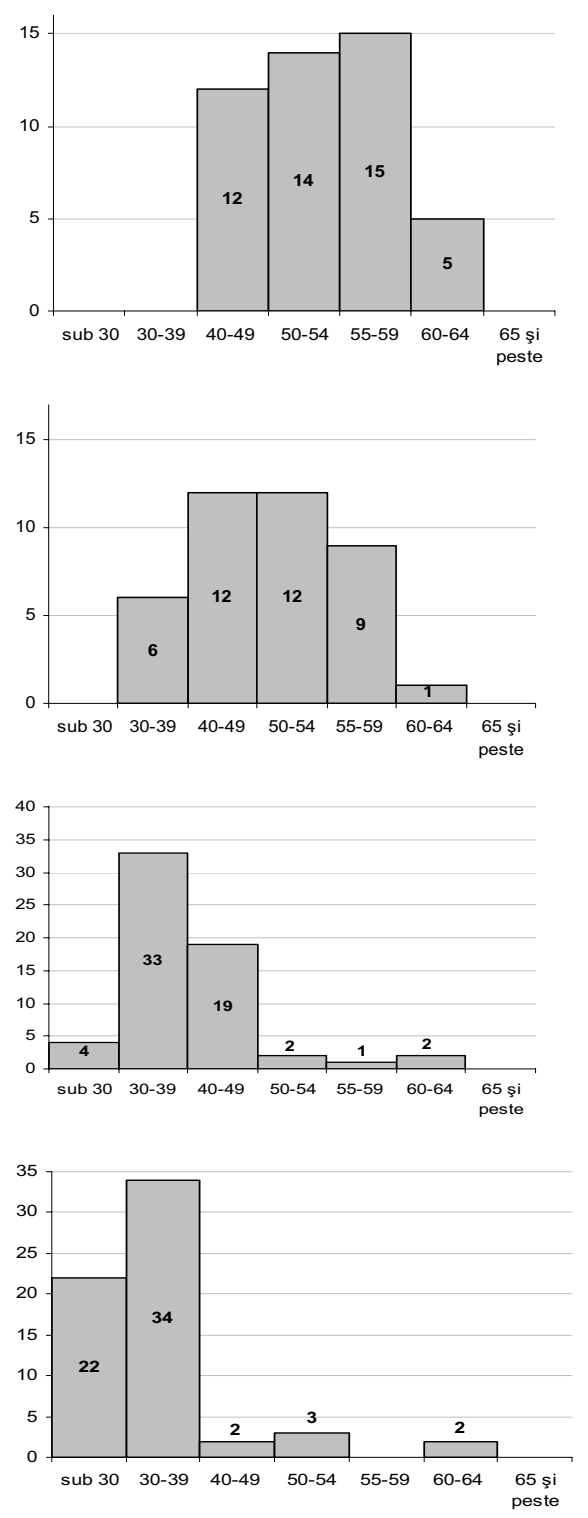

professor

lecturers

readers

\section{assistent}

University year 2009-2010
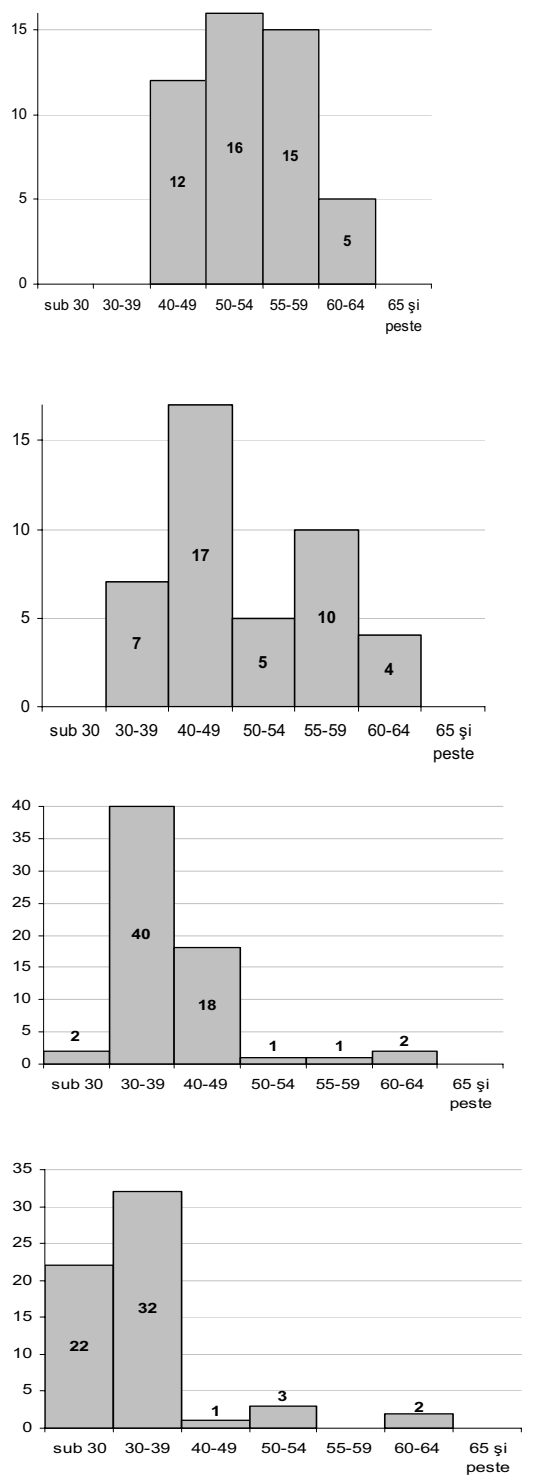

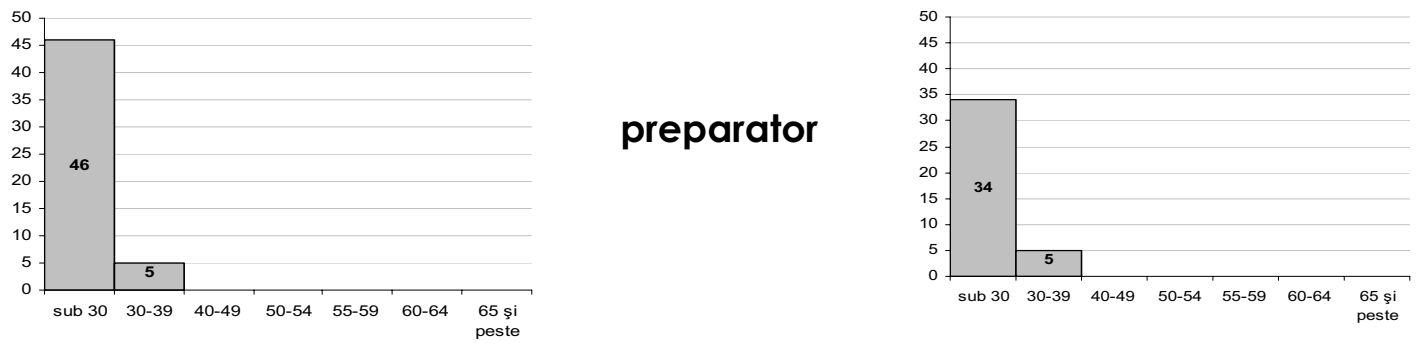

Figure 3. Distribution by age groups and by educational degrees of the number of teaching staff at the begining of the last two university years

The coverage degree by holding teaching posts decreased from $72 \%$ in the2008/2009 academic year to $63.6 \%$ this academic year, fall due to the increasing curriculum and students on the one hand and the reductionnumber of teachers on the other hand. If in the license programs in the 2008/2009 academic year about 20 students were per teacher, in this academic year there are about 21.5 students.

In all forms of education and existing programs, the average number of students per teacher increased from 25.4 to 29.2 .

It has increased the level of training and recognition of the university teachers, not only by increasing the number of higher educational degrees, but by completing a doctorate. Therefore, the number of PhDs in Science earlier this year was of 144 persons $(9.1 \%$ over the previous year, respectively 12 persons).

The share of the teachers with an academic title of doctor increased in total from $50.4 \%$ to $56.5 \%$ at the beginning of this academic year.

The material basis of the university has developed and modernized considerably this year through further investment and putting into use almost the entire D building, by modernizing and developing the library, the cafeteria, but also housing for students. The number of lecture and classrooms at the beginning of this academic year is 2,7 times higher than the previous year ( +27 rooms) and the seminar rooms with $19.6 \%$ higher $(+11$ rooms).

Table 1. Material basis of University "V. Alecsandri" in Bacau at the beginning of the academic year 2009/2010 and dynamics of the previous year

\begin{tabular}{|l|r|r|r|r|}
\hline & \multicolumn{2}{|c|}{$\begin{array}{c}\text { Material basis in early } \\
\text { education }\end{array}$} & $\begin{array}{c}\text { Dynamics } \\
(\%)\end{array}$ & $\begin{array}{c}\text { Dynamics } \\
(+/- \\
\text { nomber })\end{array}$ \\
\cline { 2 - 5 } & $2008 / 2009$ & $2009 / 2010$ & & 27 \\
\hline Material basis & & & & \\
\hline Lecture and classrooms & 16 & 43 & 268,8 & 11 \\
\hline Seminar rooms & 56 & 67 & 119,6 & -1 \\
\hline Physical education rooms & 3 & 2 & 66,7 & 5 \\
\hline Laboratories & 38 & 43 & 113,2 & -2 \\
\hline School Workshops & 3 & 1 & 33,3 & 2 \\
\hline Sport playgrounds & 3 & 5 & 166,7 & 312 \\
\hline Computers total, of which: & 541 & 853 & 157,7 & 291 \\
\hline - used in education & 516 & 807 & 156,4 & 217 \\
\hline \multicolumn{1}{|c}{ students } & 464 & 681 & 146,8 & 74 \\
\hline - teaching staff & 52 & 126 & 242,3 & 21 \\
\hline - Management used & 25 & 46 & 184,0 & 172 \\
\hline - connected to the Internet & 515 & 687 & 133,4 & \\
\hline Source: calculations after D.J.S. Bacau data & & & & \\
\hline
\end{tabular}




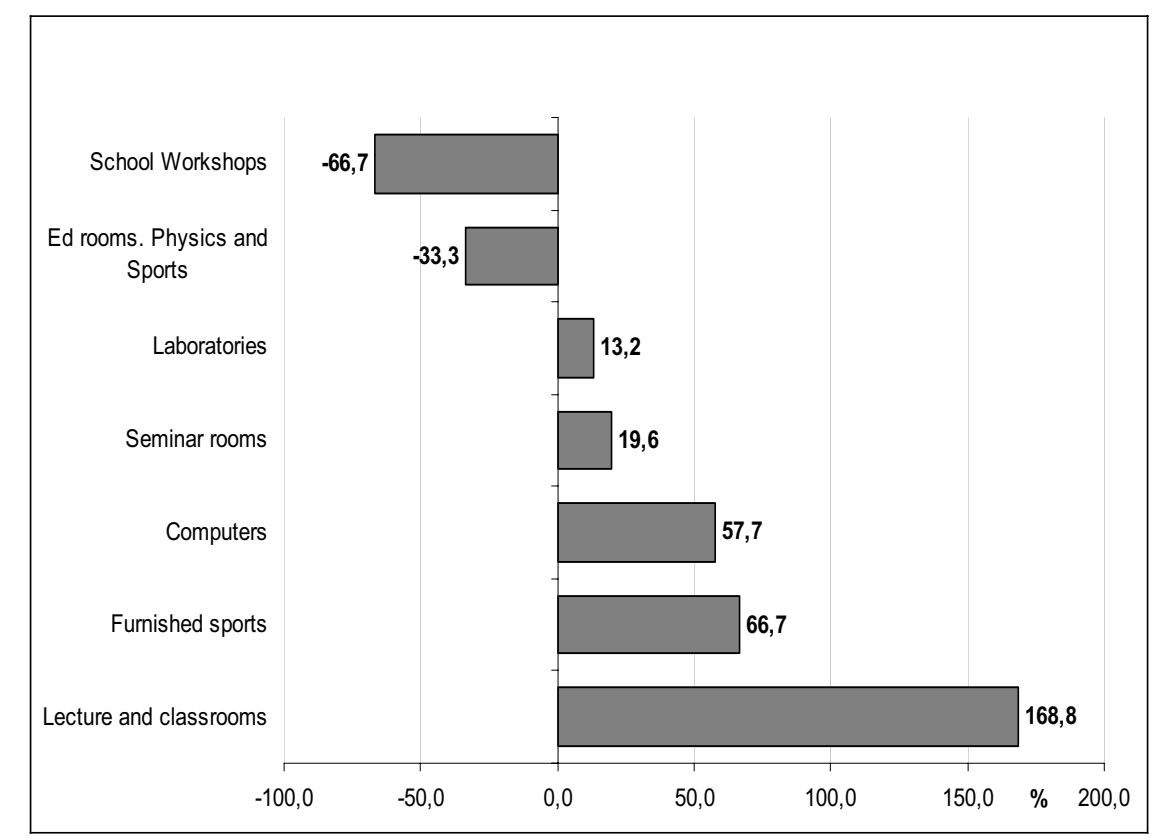

Figure 4. Dynamics (+/-\%) of the material basis at the begining of the university year (2009/2010 unlike 2008/2009)

It grew 1.5 times the number of computers in the beginning of this academic year $(+312$ pieces), $94.6 \%$ of them being used in education ( $84.4 \%$ by students and $16.6 \%$ by teachers). The number of computers connected to the Internet increased by $33.4 \%$, reaching 687 at the beginning of the year.

Given that the material and equipment investment in the university will continue in this calendar year, it is even more obvious the overall development and modernization of the educational conditions of the "Vasile Alecsandri" University from Bacau.

\section{Bibliografie}

1. Harja, E. (2009), Statistică şi Econometrie, Ed. Alma Mater, Bacău

2. Harja, E. (2010), Marketing, Raport de evaluare internă pe anul 2009 al C.R.D.F.C. al Universității „Vasile Alecsandri” Bacău

3. Jaba, E. (2005), Statistică, Ed. Economică, Bucureşti

4. Institutul Național de Statistică, (2009), Anuarul Statistic al României, Bucureşti

5. www.ub.ro

6. $\quad \underline{w w w . i n s s e . r o}$ 